\title{
Challenges of Small Scale Industries in Sustainable Development in Nigeria.
}

\author{
Arinze Gabriel Onukwuli ${ }^{1}$, Uche G Akam Ph.D², Ebele Mary Onwuka Ph.D \\ ${ }^{I}$ School Of Business, Federal College Of Education (Technical) Umunze, Anambra State, Nigeria \\ ${ }^{2}$ Department $O f$ Business Administration, Anambra State University, Igbariam \\ ${ }^{3}$ Department Of Business Administration, Nnamdi Azikiwe University, Awka, Anambra State, Nigeria.
}

\begin{abstract}
The study examines the challenges of small scale industries in sustainable development and employment generation in Anambra State, Nigeria. A sample size of 204 (managers of small scale industries in Anambra State) respondents determined at 5\% level of significance for sample error, using Eastman Kodak's sample size for inventory population was selected from a population of 12,627 managers using stratified random sampling method for the purpose of questionnaire administration. Z-test statistic for population proportion was conducted to test the variation of opinion on challenges' affecting small scale industries sustainability and employment generation. Results revealed that small scale industries in Anambra State exist in an environment characterized by both internal and external challenges which impact negatively on sustainability and employment generation. Variables identified as hindrances and were termed: credit is not often assessable; managerial competence; technology; research and development; and credit records are internal factors. While corruption and crime; multiple taxation; high competition and infrastructural base are external factors. The study calls for the financial regulatory system and government intervention in today's volatile operating environment. Therefore, the financial system is urged to extend credit facilities with mineral interest rates and stimulus packages to small scale industries while the various tiers of government should deal decisively with crime and corruption in both public and business communities coupled with streamlined taxation and improvement in infrastructural base.
\end{abstract}

Keywords: Employment Generation, Environmental Challenges, Small Scale Industries, Sustainable Development,

\section{Introduction}

Small scale enterprises sector has been recognized as an integral component of economic development and a crucial element in the effort to lift countries out of poverty [1]. Onwuka and Ile [2] posited that the reason why government attention has always been on the small scale enterprises is that the total aggregate of small scale enterprises has the potential for accelerating the pace of economic development of the country and has successfully played positive role in the economic life of Nigerian in the rural areas. Most often, small scale industries make more efficient use of inputs like idle resources, local raw materials, capital and labour than larger industries [3].

Poverty is becoming an obvious phenomenon worldwide and in line with Ikoni [4], poverty is noticeable in all parts of the world but the extent, severity and characteristics of poverty may differ within and across countries. Ajala and Fakoye in Ogbuabor, Malaolu and Elias [5] confirmed that poverty is more pronounced in developing countries such as Sub-Saharan African and South Asia. According to UNDP [6] reports, the human poverty index (HPI) value for Nigeria was 36, ranking 114 out of 135 countries measured. This was in line with Ogbuabor et. al., [5] that 50\% of Africa's population lives below the poverty line, while in Nigeria about $70 \%$ of the population are poor.

What necessitates this study is the Nigerian vision of being counted among the first twenty economies in the world by 2020 cannot be attained in a socio economic milieu of hunger, poverty and unemployment among a large segment of its population. However this will only be a reality if the necessary imperatives that meets the need of the present generation without compromising the ability of future generation to meet their need. According to Ogbuabour et. al., [5] the concept of small scale enterprise offers a variable policy option in the fight against poverty and unemployment in Nigeria.

\subsection{Conceptual Review}

\section{Review Of Related Literature}

There is no single criterion for classifying business enterprises as small or medium scale business globally. However, evidence from literature shows that in defining small scale business, reference is usually made to some quantifiable measures such as; number of people employed by the enterprises, investment outlay, the annual turnover (sales) and the asset value of the enterprises or a combination of these measures (Olabisi et. 
al., [1]. Olagunju [11] taking into consideration the reality of Nigeria situation, views small scale business enterprises to include all business venture which are set up to provide one satisfaction (utility) or the other for a defined market target and with capital and asset base as low as N5,000 and as high as N1,000,000. Onwuka and Ile [2] defined small scale business as 'any manufacturing plants employing fewer than five hundred workers, investing not more than eight hundred thousand dollars $(\$ 800,000)$ or one million dollars $(\$ 1,000,000)$ and which does dominates its industry'. Olayiwola and Ogundele [12] opined that a small scale industry is an industry with labour size of between $11-100$ or a total cost of not more than N50 million, including working capital but excluding cost of land. Fabayo, [13] classify small scale business in Nigeria into three sectors: Production sector including agricultural processing, manufacturing and mining; Service sector and Trading sector including wholesale and retails.

This study will take on the productive sector (manufacturing) of Fabayo [13] with Olayiwola and Ogundele [12] classification of an enterprise with labour size of between $11-100$ or a total cost of not more than N50 million, including working capital and excluding cost of land.

Sustainable development as an evolving concept, which is continually redefined and reinterpreted can be formally stated as a twin principle of intra and inter-generational equity [14]. The world council for environment and development [15] defines sustainable development as development that meets present needs without compromising the ability of future generation to meet their own needs. In other word, it is that development that can stand a test of time. Sustainability implies the need to depart from hither to dominant models of development that fail to balance the need of people and the planet in the pursuit of peace and prosperity [16]. The sustainability debate anchored on the assumption that societies need to manage three types of capital (economic, social and natural), which may be non-substitutable and whose consumption might be irreversible [17]. It emphasized the importance of capacity building and by capacity building Obi [18] opines that is an externally or internally initiated process designed to help individuals and groups to appreciate and manage their changing circumstances, with the objective of improving the stock of human, social, financial, physical and natural capital in an ethically defensible way.

Anyadike et. al., [19] in their studies on entrepreneurship development and unemployment generation in Nigeria, relying extensively on current articles from other scholars on entrepreneurship development and government statistical documentation defined unemployment as the conglomerate of youth with diverse background, willing and able to work, but cannot find any. Employment generation according to American economic association committee in Ogbuabor et. al., [5] means the availability of employment so that those qualified people who seek job at prevailing rates can find them in productive activities without considerable delay.

\section{$2.2 \quad$ Theoretical Review}

The theoretical foundation of this study anchored on;

The vicious circle of poverty theory, and

The unbalanced growth theory

The vicious circle of poverty theory was propounded by Nurkse [20], posits that there are circular relationships known as the vicious circles of poverty that tend to perpetuate the low level of development in less developed countries like Nigeria. In other words, there is a circular related forces tending to act and react upon one another in such a way as to keep a country in a state of poverty. For instance, a poor man not having enough to eat, being under fed, his health may be weak, being physically weak, his working capacity is low, which means that he is poor, which in turn means that he will not have enough to eat and so on. The basic vicious circle stems from the fact that total productivity in low income countries is low due to deficiency of capital market imperfections, economic backwardness and underdevelopment, and this circle operated both on demand and supply sides [5]. The significant of the vicious circle of poverty theory to this study is that poverty once started could continue for generation unless there is outside intervention. This intervention may be in form of tackling the challenges of small scale industries in sustaining development and employment generation in Nigeria.

The theory of unbalance Growth postulated by Hirschman [20] states that advanced and deliberately unbalancing the economy according to pre-designed strategy is the best way to achieve economic growth in an underdeveloped country. According to this theory investment should be in selected sectors rather than simultaneously in all sectors of the economy. The significant of this theory to the study is that investment in strategically selected industries (small scale industries) of the economy will lead to new investment opportunity, employment generation so as to pave the way for further economic development.

\subsection{Empirical Review.}

Akeredolu in Ogbuabor et. al, [5] examined 52 indigenous small scale enterprises in Lagos State, Nigeria in order to establish the relationship between small scale enterprises and poverty reduction. The findings 
indicate that one of the most effective ways of poverty reduction in Lagos State is the development of small scale enterprises. The business environment has a significant impact on the growth of small scale enterprises. For small scale enterprises to grow, it is important to strengthen not only the internal business environment but also the external business environment. This was in line with the World Bank [14] report that environment have either a negative or positive effect on the growth or failure of small scale enterprises in Africa.

Kadiri [22] explored the contributions of small scale enterprises to employment generation in Nigeria by providing sectorial analysis of the efficacy of small scale enterprises as a vibrant tool for employment generation. The Bionomical logistic regression analysis was explored as the tool for statistical analysis. Result of the study shows that the sector was unable to achieve this goal due to its inability to obtain adequate business finance. Onakoya, Fasanya and Abdulrahman [23], studies on the impact of financing small scale enterprises on economic growth in Nigeria, using quarterly time series data for 1992 to 2009. The results reveal that loan to small scale enterprises have a positive impact on the economic performance while interest rate has a negative impact on economic growth. They concluded that the worst obstacle confronting small scale industries in Nigeria is managerial capacity, and access to capital or finance. Ighoroje and Oboro [24] examined the problems of financing small scale business enterprises in Nigeria and the way forward. The study identified the sources of finance, types of finance available for small business enterprises and problem inhibiting business enterprise in Nigeria in securing funds for the smooth operation. The study concluded that adequate finance is indispensable for the successful operations of small scale enterprises in Nigeria. Ikeanyionwu [25], study on entrepreneurship skills for effective management of small scale business by entrepreneurs in Onitsha North local government area of Anambra State. Result from the analysis shows that financial management skills which form the bedrock upon which the success of any business can rest and grow are highly needed, other skill which are highly needed are administrative skills, professional skills and information technology skills.

Akighir [26] work on rice processing and poverty reduction in Kwanda local Government Council of Benue State Nigeria, The study measured poverty status using head count ratio and poverty gap measures. The findings showed that rice processing reduced the poverty status of the respondents. The study identified the challenges of rice processing to include; low capital, poor transportation network and low price of locally processed rice among others. Idemobi [7], study on the problem of sustaining the growth of small scale and medium enterprises in a typical Sub-Saharan African context applying Chi-square inferential statistic to sample of 120 participants. The results found that poor infrastructural facilities (especially electricity, water and roads), lack of access to formal source of credit, high incidence and prevalence of violent crime leading to high operational costs are the major impediments to sustaining the growth and survival of small and medium enterprises. The study specifically found that due to the high cost of production especially the high cost of self generated electricity, small and medium enterprises collapse at an alarming rate in Nigeria. The World Bank report in Onukwuli, Nwagbala, Ofodile and Umeifekwem [27] found out that about 70\% of small scale enterprises perceived corruption as an impediment to the firms. According to Umolu in Mba, [28] many developing countries suffer from deplorable State of basic infrastructure (transportation, telecommunication, and electricity). They indicated that part of alternative source of power to business in any part of Nigeria is about one third of overall operation cost.

Scholars have indicated that starting a business is a risky venture and warn that the chances of small scale business owners making it past the five year mark are very slim [1]; [7]. Successive Nigeria Government has instituted poverty alleviation programs and job creation schemes through small scale businesses to alleviate these problems of poverty and unemployment. Some of the programs include; National Economic Empowerment and Development Strategy (NEEDS) in 2004; National poverty Eradication Programs (NAPEP) in 2001; the National Directorate of Employment (NDE) in 1986; and Green Revolution (GR) in 1980.

Despite the efforts, supports and incentive programs to small scale industries in Nigeria, Akabueze [8] clearly stated that it would seem reasonable to expect that small scale business would grow and flourish but the rate of business failure continues to increase creating unemployment problem and poverty. According to NBS [9] and Suleiman [10], the unemployment rate in Nigeria increased from $11.9 \%$ in 2005 to $12.7 \%$ in 2007 , $14.9 \%$ in $2008,19.7 \%$ in $2009,21.4 \%$ in $201023.9 \%$ in 2011 . Nigeria's poverty incidence increased from $54.4 \%$ in 2004 to $69 \%$ in 2010 . While the population in poverty increased from 68.7 million in 2004 to 112.5 million in 2010.

The problem of the study is to locate what could be the internal and external environmental challenges for the high failures of small scale enterprises in Anambra State, Nigeria. The main objective of this study is to explore the environmental constraints which could lead to non sustainability of small scale enterprises in Anambra State, Nigeria. Specifically, the study intends to:

1. Identify the internal environmental constraints affecting small scale enterprises sustainability and employment generation in Anambra State.

2. Identify the external environmental constraints affecting small scale enterprises sustainability and job creation in Anambra State. 
In order to achieve these objectives the following questions were answered.

1. What are the internal environmental constraints that hinder small scale industries sustainability and employment generation in Anambra State, Nigeria?

2. What are the external environmental challenges that pose obstacle to small scale industries sustainability and job creation in Anambra State, Nigeria?

Arising from the background study, subsequent objectives of the study and research questions, the following hypotheses were generated and tested:

Ho1: There is no significant variation between internal constraints of small scale industries sustainability and employment generation.

Ho2: There is no significant variation between external constraints of small scale enterprises sustainability and employment creation.

\section{Materials And Methods}

The survey research design method was used in the study. It involves using self designed sustainability and employment generation questionnaire. The population of the study consists of all small scale enterprises that engage in productive venture located in Anambra state. According to Olayiwola and Ogundele [12] the size of business that fall into this category are those that employ between eleven (11) and one hundred (100). Statistics provided from the registry of business and social development in the 21 local government council headquarters of Anambra State show that the population of this level of small scale enterprises still operating in this area is twelve thousand six hundred and twenty-four $(12,624)$. A sample size of 225 participants determined at $5 \%$ level of significance for sample error using Eastman Kodak's sample size for inventory population formular [29] was selected using proportionate stratified random sampling method for purpose of questionnaire administration.

The instrument used in the study is closed-ended questionnaire. The questionnaire comprises of two sections or parts. The scale used to measure the internal challenges construct in this study were derived from instruments designed from previous study in which their reliability and validity were checked and reported.

Five internal environmental obstacles associated with sustainability and employment generation were selected for analysis. The scale used to measure these five factors had already been constructed, used and tested by Onukwuli et. al.,[27]. Each scale modified to four point likert-scale items. Degree of agreement varies from 1 4 representing " 1 " for strongly disagree, " 2 " for disagree " 3 " for agree and " 4 " for strongly agree. Onukwuli et. al., [27] disclosed reliability by a test-retest using Pearson product moment correlation coefficient which yields 0.78 for internal environmental challenges.

Questions in external sustainability and employment generation of small scale enterprise were also adapted and modified from previous research. The scale was constructed from four commonly used global items like, generally speaking high competition affects your enterprise; crime, corruption and security of life and property is a threat to survival and sustainable development of the enterprise; cost of doing business is high; and failure of the government to provide good infrastructural base (water, electricity, effective communication system, good road network to people and business environments). In order to establish the reliability of the instrument, a pilot study was carried out on a sample of 20 managers of the small scale industries operating at Nkpor, Idemili North Local Government area, Anambra State using test-retest method. The reliability test was 0.82 , hence reliable.

The sustainable development and employment generation questionnaire responses of the respondents were analyzed using mean score criterion $($ mean $=2.5$ ) on a four point scale, while Z-test score for population proportion was used to test the hypotheses at $5 \%$ level of significant. A total of 225 copies of the sustainable development and employment generation questionnaire administered out of which five were not properly completed while 16 were not returned and 204 (90.7\%) were used for analysis.

\section{Results}

The research questions formulated for this study were analyzed using mean score criterion. In other to answer the research question one which states, "What are the internal environmental challenges of small scale industries that hinder sustainability and employment generation in Anambra State"? Mean score criterion on responses to questionnaire on firms' internal obstacles of small scale enterprises sustainability and employment generation was employed. We accept as a factor if the mean score associated with a variable is equal or greater than 2.5 and reject as a factor if the mean score associated with it is less than 2.5. The variable "credit is often not assessable because of the cost of procuring it from the market based source" recorded the highest factor with mean score of 3.19 while "establishment not easily located and networked to either crucial buyers or sellers" variable recorded the least with mean score 2.54 . Therefore the four factors are more than 2.5 mean scores and are accepted as factors that hinders effective sustainability and employment generation in small scale enterprises in Anambra State, Nigeria. 
To answer the research question two which state "What are the external environmental challenges of small scale enterprises that hinders sustainability and employment generation in Anambra State, Nigeria. Result of the analysis on firms external challenges indicated that the variables high competition; crime and corruption; cost of doing business; and failure of government to provide good infrastructural base recorded above 2.5 on a four point scale. Corruption, crime, security of life and property has shown the most important external challenges to small scale enterprises sustainability and employment generation. The overall or weighted mean score for external variables is 2.68 .

Hypothesis one which states, "there is no significant variation in the opinion of the respondents on internal constraints of small scale enterprises sustainability and employment generation in Anambra State Nigeria was tested for significance using Z-test Statistic. The summary of results is shown in Table one.

Table 1: Summary of Z-test statistic and significance results on internal environmental constraints of small scale enterprises sustainability and employment generation.

\begin{tabular}{lccccc}
\hline Variables & $\mathrm{n}$ & $\begin{array}{c}\text { significance } \\
\text { Level }(\propto)\end{array}$ & $\begin{array}{c}\text { Z- statistic values } \\
\text { Z-cal }\end{array}$ & Z-crit & $\begin{array}{c}\text { decision rule } \\
\text { on null hypothesis }\end{array}$ \\
\hline $\begin{array}{l}\text { Internal environmental } \\
\text { constraints on sustainability } \\
\text { and employment generation }\end{array}$ & 204 & 0.05 & 0.14 & \pm 1.96 & Accepted \\
\hline
\end{tabular}

Source: Results of empirical data, 2014.

Table 1 above, shows that $\mathrm{a}, \pm \mathrm{Z}\left(\frac{\alpha}{2}\right)= \pm \mathrm{Z}(0.25)= \pm 1.96$ is required for significance (two tailed test). Since the calculated $\mathrm{Z}(0.14)$ is less than critical $\mathrm{Z}( \pm 1.96)$ we accept the null hypothesis and conclude that there was no significant variation between the opinions of managers or its representatives on internal constraint affecting small scale enterprises sustainability and employment generation in Anambra State, Nigeria.

Hypothesis two which states, "there is no significant variation in the opinion of the respondents on external constraints of small scale enterprises sustainability and employment generation in Anambra State, Nigeria was tested for significance using Z-test Statistic. The summary of results is shown in Table two.

Table 2: Summary of Z-test statistic and significance results on external environmental constraints of small scale enterprises sustainability and employment generation

\begin{tabular}{|c|c|c|c|c|c|}
\hline Variables & $\mathrm{n}$ & $\begin{array}{r}\text { significance } \\
(\propto)\end{array}$ & $\begin{array}{c}\text { Z- statistic values } \\
\text { Z-cal }\end{array}$ & Z-crit & $\begin{array}{l}\text { decision rule } \\
\text { on null hypothesis }\end{array}$ \\
\hline $\begin{array}{l}\text { External environmental } \\
\text { constraints on sustainability } \\
\text { and employment generation }\end{array}$ & 204 & 0.05 & 0.13 & \pm 1.96 & Accepted \\
\hline
\end{tabular}

Source: Results of empirical data, 2014

Table 2 above, shows that $\mathrm{a}, \pm \mathrm{Z}\left(\frac{\alpha}{2}\right)= \pm \mathrm{Z}(0.025)= \pm 1.96$ is required for significance (two tailed test). Since the calculated $\mathrm{Z}(0.13)$ is less than critical $\mathrm{Z}( \pm 1.96)$, we accept the null hypothesis and conclude that there was no significant difference between the opinions of managers or its representatives on external constraint affecting small scale enterprises sustainability and employment generation in Anambra State, Nigeria

\section{Disscussion Of Results}

The first hypothesis which states 'there is no significant variation between internal environmental constraints of small scale industries sustainability and employment generation' was accepted. This shows that internal obstacles encountered by small scale Industries in Anambra state affected their sustainability and employment generation. The finding of this study agrees with the work of Nurkse [20] in his theory of vicious circle of poverty. Result shows that the vicious circle of internal environmental constraints of small scale industries once started could affect total productivity, economic backwardness, sustainability and employment generation. The findings also have collaborated with the works of Ikeanyionwu [25]; Ighoroje and Oboro [24]; Kadiri [22]; and Onakoya et. el., [23] that managerial competence; credit not often accessible; and enterprise not easily net worked is proved to have adverse relationship with small scale sustainability and employment generation.

The second hypothesis which states that 'there is no significant variation between external environmental constraints of small scale industries sustainability and employment generation' was accepted. 
The result of interpretation agrees with work of Idemobi [7] on the problem of sustaining the growth of small and medium enterprises in a typical Sub Saharan African context. The result found that poor infrastructural facilities, high incidence and prevalence of crime leading to high operational cost are the major impediments to sustaining the growth and survival of small scale and medium enterprises. The finding also collaborated with the work of Umolu in Mba [28] that the alternative source of power to business in any part of Nigeria is about one third of overall operation cost

\section{Conclusion And Recommendations}

The aggregate of small scale industries has the potential for accelerating the pace of economic development and employment generation of the country and has successfully played positive role in the economic life of Nigerians in the rural areas. For small scale industries to perform such functions effectively these challenges in the business environment must be addressed. The obstacles as identified and examined in the study include; credit is not often assessable; competence and managerial skills are lacking; information technology; and investment in research and development. Others are bad credit record; corruption, crime and security of life and property; high cost of doing business; high competition and weak infrastructural base.

Based on these findings, this research work recommends that; the financial system is urged to extend credits facilities with minimal interest rate as a means of resolving the challenges of credit not often assessable and empowering emerging small scale industries through stimulus packages. More so, there is need for the various tiers of government to deal decisively with crime and corruption in both public and business community coupled with streamlining the multiple taxation and finally improvement in infrastructural facilities.

\section{References}

[1]. S Olabisi, A.A. Olagbemi, and A.A Atere, A. A, Factors affecting small-scale business performance in informal economy in Lagos State-Nigeria: A gendered based analysis, Journal of Business and General Education, 5(1), 2013, 25-37.

[2]. E.M. Onwuka, and C.M. Ile, Entrepreneurship development: conceptual, theoretical and practical framework- company goals (Ekwulobia: Jossy Printing Press, 2006).

[3]. C.P. Okenwa, Entrepreneurship development in Nigeria: A practical approach (Enugu: Snaap press Ltd, 2005)

[4]. U.D. Ikoni, Women productivity and poverty alleviation, Journal of Economics and Social Research, 3(1) 2004, 1-12

[5]. J.E. Ogbuabor, V.A. Malaolu, and T.I. Elias, Small scale enterprises, poverty alleviation and job creation in Nigeria: Lessons from Burnt Bricklayers in Benue State, Journal of Economics and sustainable Development, 4(8), 2013, 120-134.

[6]. UNDP, Human Development Report, (New York: Oxford University Press, 2009).

[7]. E.I. Idemobi, The problem of sustaining the growth of small and medium enterprises in a typical Sub-Saharan, African context, African Journal of social sciences, 2(1), 2012, 15-24.

[8]. B. Akabueze, Financing small and medium enterprises (SMES): The small and medium industries Equity Investment Scheme (SMIEIS) option (Lagos: N.C press, 2002).

[9]. National Bureau of Statistics, Poverty profile for Nigeria: Strategy support program, International food policy research institute, 2012, retrieved from http//www.nigerianstat.gov.ng/uploads/latestreease on 21/2/2012.

[10]. A. Suleiman, Poverty profile for Nigeria: A guide for social change led and with young people, (London: the free child project, 2013).

[11]. Y.A. Olagunju, Entrepreneurship and small scale business enterprises development in Nigeria, (Ibadan: University press, 2004)

[12]. P.O. Olayiwola, and O.J.K. Ogundele, Enhancing the role of entrepreneurship in creating active macro business and SMEs to meet the challenges of vision 2020, Journal of Entrepreneurship and Small Business Development (JESBD) 1(1), 2010, 1-9.

[13]. J.A. Fabayo, Small and medium enterprises development strategy: a critical option for sustainable long-term economic development in Nigeria, First Annual International Conference on effective management of small and medium scale enterprises for sustainable economic development, Abraham Adesanya Polytechnic, Ijebuode, 2009.

[14]. World Bank, Nigeria, poverty in the midst of plenty: The challenge of growth with inclusion (Washington: World Bank, 2006)

[15]. WSSD, The concept of sustainable development, 2002, retrieved from www.ilo.org/public/english/llra/document/congress/Regional/lagos2011/5th session/session 5a/smellscaleent.pdt

[16]. A. Wals, Learning for a sustainable world review of contests and structures for education for sustainable development, (Paris: UNESCO, 2009).

[17]. T. Dylick, and K. Hockerts, Beyond the business case for corporate sustainability, Business Strategy and the Environment, 11(2), 2002, 130-141.

[18]. O. Obi, Promoting human capacity building, a paper presented at Njikoka Local Government, Council, for HPM's planning officers, Treasurers and other relevant officers from Grade level 12 and above, Abagana,2007.

[19]. N. Anyadike, I.K. Emeh, and F.O. Ukah, Entrepreneurship development and employment in Nigeria: problems and prospect, Universal Journal of Education and general Studies, 1(4), 2012, 88-102.

[20]. R. Nurkse, Problem of capital formation in under-developed countries (Oxford: Black Well, 1953).

[21]. A.O. Hirschman, The strategy of economic development (New Haven: Tale University Press, 1958).

[22]. I.B. Kadiri, Small and medium scale enterprises and employment generation in Nigeria: The role of finance, Kuwait Chapter of Arabian Journal of Business and Management Review, 1(9), 2012, 79-93.

[23]. A.B.O. Onakoya, I.O. Fasanya, and H.D. Abdulrahma, Small and medium scale enterprises financing and economic growth in Nigeria, European Journal of Business and Management, 5(4), 2012, 130-136.

[24]. E.J. Ighoroje, and O.G. Oboro, Financing small scale business enterprises in Nigeria: A review of the problems and the way forward, International Journal of Economic Development Research and Investment, 2(3), 2011, 134 - 137.

[25]. C. Ikeanyionwu, Entrepreneurship skills for effective management of small bcale business in Onitsha, M.sc thesis, department of Vocational and Adult Education Nnamdi Azikiwe University, Nigeria, 2006.

[26]. D.T. Akighir, Rice processing and poverty reduction in Kwande local government, M,sc thesis, Benue State University, Nigeria, 2011. 
[27]. G.A Onukwuli, S.C. Nwagbala, R.N. Ofodile, and C.M. Umeifekwem, Entrepreneurship sustainability in a developing economy, Journal of Business and General Education, 5(1), 2013, 25-37.

[28]. S.I. Mba. Development of small and medium scale enterprises for employment creation and poverty alleviation as a key strategy for sustainable economic development in Nigeria, Proc. $1^{\text {st }}$ International Conference on Policy Reforms for Sustainable Development in Nigeria, Anambra State University, Igbariam,1(1),2012, 158-167.

[29]. E.U.L. Imaga, Theory and practice of production and operation management, $3^{\text {rd }}$ edition (Enugu: Rhyce Kerex Publishers, 2003). 